\title{
Taurolidine Sensitivity of Eryptosis, the Suicidal Erythrocyte Death
}

\author{
Madeline Fink ${ }^{\mathrm{a}} \quad$ Abdulla Al Mamun Bhuyan ${ }^{\mathrm{a}} \quad$ Nefeli Zacharopoulou $^{\mathrm{b}}$ \\ Florian Lang \\ aDepartment of a Cardiology, Eberhard-Karls-University, Tuebingen, bDepartment of Cardiovascular \\ Medicine and Physiology, Eberhard-Karls-University, Tuebingen, Germany
}

\section{Key Words}

Phosphatidylserine $\cdot$ Cell volume $•$ Eryptosis $•$ Calcium

\begin{abstract}
Background/Aims: The taurine derivative Taurolidine is effective against diverse bacteria and tumor growth. In the treatment of cancer, the substance is effective in part by triggering suicidal death or apoptosis of tumor cells. The Taurolidine-induced apoptosis involves mitochondria. Erythrocytes lack mitochondria but are nevertheless able to enter suicidal erythrocyte death or eryptosis, which is characterized by cell shrinkage and cell membrane scrambling with phosphatidylserine translocation to the erythrocyte surface. Signaling of eryptosis includes increase of cytosolic $\mathrm{Ca}^{2+}$ activity $\left(\left[\mathrm{Ca}^{2+}\right]_{i}\right)$, oxidative stress and ceramide. The present study explores, whether Taurolidine induces eryptosis and, if so, which cellular mechanisms are involved. Methods: Phosphatidylserine exposure at the cell surface was estimated using annexin-V-binding, cell volume using forward scatter, $\left[\mathrm{Ca}^{2+}\right]_{i}$ using Fluo3fluorescence, reactive oxygen species (ROS) formation using $2^{\prime}, 7^{\prime}$-dichlorodihydrofluorescein (DCF)-dependent fluorescence, and ceramide abundance using specific antibodies. Results: A 48 hours exposure of human erythrocytes to Taurolidine $(60 \mu \mathrm{g} / \mathrm{ml})$ significantly enhanced the percentage of annexin- $V$-binding cells, significantly decreased forward scatter and significantly increased Fluo3-fluorescence and ceramide abundance, but not DCF-fluorescence. The effect of Taurolidine on annexin-V-binding was virtually abrogated by removal of extracellular $\mathrm{Ca}^{2+}$. Conclusion: Taurolidine triggers cell shrinkage and phospholipid scrambling of the erythrocyte cell membrane, an effect at least in part due to $\mathrm{Ca}^{2+}$ entry and paralleled by increase of ceramide abundance.
\end{abstract}




\section{Introduction}

Taurolidine is an effective antibacterial substance [1-8] utilized to counteract catheterrelated infections [9-24]. The substance is further effective against malignancy both, in vivo and in vitro [25-29]. Taurolidine curtails tumor blood supply by suppressing angiogenesis $[29,30]$. Most importantly Taurolidine triggers suicidal tumor cell death or apoptosis [28-30], an effect involving mitochondria [29, 30]. Moreover, it generates oxidative stress specifically in tumor cells [28]. Side effects of taurolidine include liver injury [31] and stimulation of nociception [32].

Erythrocytes lack mitochondria, but may, in analogy to apoptosis, enter suicidal death of erythrocytes or eryptosis [33-35], which is characterized by cell shrinkage [36] and cell membrane scrambling with phosphatidylserine translocation to the cell surface [33]. Cellular mechanisms orchestrating eryptosis include increase of cytosolic $\mathrm{Ca}^{2+}$ activity $\left(\left[\mathrm{Ca}^{2+}\right]_{\mathrm{i}}\right)[33]$, ceramide [33], caspases [33, 37, 38], G-protein Galphai2 [39], casein kinase $1 \alpha$ [33], Janus-activated kinase JAK3 [33], protein kinase C [33], and p38 kinase [33]. Eryptosis is suppressed by AMP activated kinase AMPK [33], cGMP-dependent protein kinase [33], mitogen and stress activated kinase MSK1/2 [40], and PAK2 kinase [33]. Eryptosis may be triggered by hyperosmotic shock [33], oxidative stress [33], energy depletion [33], radiation [41, 42], and a wide variety of small molecules [33, 40, 43-87]. Several inbitors of eryptosis have been identified [88-91]. Eryptosis is enhanced in several clinical conditions including iron deficiency [33], dehydration [33], hyperphosphatemia [33], vitamin D excess [33], chronic kidney disease (CKD) [92-97], hemolytic-uremic syndrome [98], autoimmune hemolytic anemia [99], diabetes [33], hypertension and dyslipidemia [100], hepatic failure [101], malignancy [102-104], arteritis [105], systemic lupus erythematosus [106], sepsis $[107,108]$, malaria $[33,109,110]$, sickle-cell disease [33], beta-thalassemia [33], Hb-C and G6PD-deficiency [33], Wilsons disease [107], as well as advanced age [33]. Eryptosis is fostered by storage for transfusion $[41,42,58,111]$. Erythrocytes from newborns rapidly undergo eryptosis following exposure to oxidative stress [33,112].

The present study explored, whether Taurolidine stimulates eryptosis. To this end human erythrocytes from healthy volunteers were exposed to Taurolidine and phosphatidylserine surface abundance, cell volume, $\left[\mathrm{Ca}^{2+}\right]_{i}$, ROS formation, and ceramide abundance determined by flow cytometry.

\section{Materials and Methods}

\section{Erythrocytes, solutions and chemicals}

Fresh Li-Heparin-anticoagulated blood samples were kindly provided by the blood bank of the University of Tübingen. The study is approved by the ethics committee of the University of Tübingen (184/2003 V). The blood was centrifuged at $120 \mathrm{~g}$ for $20 \mathrm{~min}$ at $21^{\circ} \mathrm{C}$ and the platelets and leukocytes-containing supernatant was disposed. Erythrocytes were incubated in vitro at a hematocrit of $0.4 \%$ in Ringer solution containing (in $\mathrm{mM}$ ) $125 \mathrm{NaCl}, 5 \mathrm{KCl}, 1 \mathrm{MgSO}_{4}, 32 \mathrm{~N}-2$-hydroxyethylpiperazine-N-2-ethanesulfonic acid (HEPES; pH 7.4), 5 glucose, $1 \mathrm{CaCl}_{2}$, at $37^{\circ} \mathrm{C}$ for 48 hours. Where indicated, erythrocytes were exposed for 48 hours to Taurolidine (Sigma Aldrich, Hamburg, Germany).

\section{Annexin-V-binding and forward scatter}

After incubation under the respective experimental condition, a $150 \mu \mathrm{l}$ cell suspension was washed in Ringer solution containing $5 \mathrm{mM} \mathrm{CaCl}_{2}$ and then stained with Annexin-V-FITC (1:200 dilution; ImmunoTools, Friesoythe, Germany) in this solution at $37^{\circ} \mathrm{C}$ for $20 \mathrm{~min}$ under protection from light. The annexin- $\mathrm{V}$ abundance at the erythrocyte surface was subsequently determined on a FACS Calibur (BD, Heidelberg, Germany). Annexin-V-binding was measured with an excitation wavelength of $488 \mathrm{~nm}$ and an emission wavelength of $530 \mathrm{~nm}$. A marker (M1) was placed to set an arbitrary threshold between annexin-V-binding 


\section{Cellular Physiology Cell Physiol Biochem 2018;51:501-512

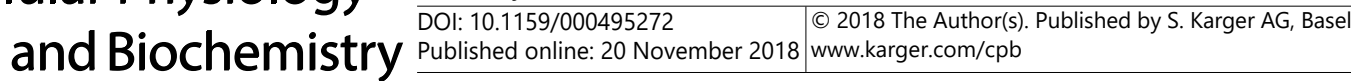

Fink et al.: Taurolidine-Induced Eryptosis

cells and control cells. The same threshold was used for untreated and Taurolidine treated erythrocytes. A dot plot of forward scatter (FSC) vs. side scatter (SSC) was set to linear scale for both parameters. The threshold of forward scatter was set at the default value of "52" [113].

Intracellular $\mathrm{Ca}^{2+}$

After incubation, erythrocytes were washed in Ringer solution and loaded with Fluo-3/AM (Biotium, Hayward, USA) in Ringer solution containing $5 \mu \mathrm{M}$ Fluo-3/AM. The cells were incubated at $37^{\circ} \mathrm{C}$ for 30 $\mathrm{min}$. $\mathrm{Ca}^{2+}$-dependent fluorescence intensity was measured with an excitation wavelength of $488 \mathrm{~nm}$ and an emission wavelength of $530 \mathrm{~nm}$ on a FACS Calibur.

\section{Reactive oxidant species (ROS)}

Oxidative stress was determined utilizing 2',7'-dichlorodihydrofluorescein (DCF) diacetate. After incubation, a $150 \mu \mathrm{l}$ suspension of erythrocytes was washed in Ringer solution and stained with DCF diacetate (Sigma, Schnelldorf, Germany) in Ringer solution containing DCF diacetate at a final concentration of $10 \mu \mathrm{M}$. Erythrocytes were incubated at $37^{\circ} \mathrm{C}$ for $30 \mathrm{~min}$ in the dark and washed two times in Ringer solution. The DCF-loaded erythrocytes were resuspended in $200 \mu \mathrm{l}$ Ringer solution and ROS-dependent fluorescence intensity was measured at an excitation wavelength of $488 \mathrm{~nm}$ and an emission wavelength of $530 \mathrm{~nm}$ on a FACS Calibur (BD).

\section{Ceramide abundance}

For the determination of ceramide, a monoclonal antibody-based assay was used. To this end, cells were stained for 1 hour at $37^{\circ} \mathrm{C}$ with $1 \mu \mathrm{g}$ anti ceramide antibody (clone MID 15B4, Alexis, Grünberg, Germany) in PBS containing $0.1 \%$ bovine serum albumin (BSA) at a dilution of 1:10. The samples were washed twice with PBS-BSA. The cells were stained for 30 minutes with polyclonal fluorescein isothiocyanate (FITC) conjugated goat anti-mouse IgG and IgM specific antibody (Pharmingen, Hamburg, Germany) diluted 1:50 in PBS-BSA. Unbound secondary antibody was removed by repeated washing with PBS-BSA. The samples were analyzed by flow cytometric analysis with an excitation wavelength of $488 \mathrm{~nm}$ and an emission wavelength of $530 \mathrm{~nm}$. As a control, secondary antibody alone was used.

\section{Statistics}

Data are expressed as arithmetic means \pm SEM. As indicated in the figure legends, statistical analysis was made using ANOVA with Tukey's test as post-test and $t$ test as appropriate. $n$ denotes the number of different erythrocyte specimens studied. Since different erythrocyte specimens used in distinct experiments are differently susceptible to triggers of eryptosis, the same erythrocyte specimens have been used for control and experimental conditions.

\section{Results}

The present study elucidated whether Taurolidine is capable to stimulate eryptosis, the suicidal erythrocyte death. In a first step, the effect of Taurolidine on cell membrane scrambling with phosphatidylserine translocation to the cell surface was determined. Phosphatidylserine exposing erythrocytes were identified from annexin-V-binding which was quantified by flow cytometry. Prior to measurements, the erythrocytes were incubated for 48 hours in Ringer solution without or with Taurolidine $(15-60 \mu \mathrm{g} / \mathrm{ml})$. As shown in Fig. 1, a 48 hours exposure to Taurolidine significantly increased the percentage of phosphatidylserine exposing erythrocytes at all Taurolidine concentrations tested.

A second hallmark of eryptosis is cell shrinkage. Erythrocyte volume was thus estimated from forward scatter which was quantified with flow cytometry. Prior to measurements, the erythrocytes were again incubated for 48 hours in Ringer solution without or with Taurolidine $(15-60 \mu \mathrm{g} / \mathrm{ml})$. As illustrated in Fig. 2, Taurolidine $(60 \mu \mathrm{g} / \mathrm{ml})$ significantly decreased the average erythrocytes forward scatter at all Taurolidine concentrations tested.

Fluo3-fluorescence was determined as a measure of cytosolic $\mathrm{Ca}^{2+}$ activity $\left(\left[\mathrm{Ca}^{2+}\right]_{\mathrm{i}}\right)$. As shown in Fig, 3, a 48 hours incubation with $15-60 \mu \mathrm{g} / \mathrm{ml}$ Taurolidine significantly increased 
Fig. 1. Effect of Taurolidine on phosphatidylserine exposure. A. Original histogram of annexin-Vbinding of erythrocytes following exposure for 48 hours to Ringer solution without (grey area) and with (black line) presence of $60 \mu \mathrm{g} / \mathrm{ml}$ Taurolidine. B. Arithmetic means \pm SEM $(\mathrm{n}=15)$ of erythrocyte annexin-V-binding following incubation for 48 hours to Ringer solution without (white bar) or with (black bars) Taurolidine $(15,30,60 \mu \mathrm{g} / \mathrm{ml})$. For comparison, the effect of the solvent DMSO (grey bar). ${ }^{*}(\mathrm{p}<0.05)$ *** $(\mathrm{p}<0.001)$ indicates significant difference from the absence of Taurolidine (ANOVA).

Fig. 2. Effect of Taurolidine on erythrocyte forward scatter. A. Original histogram of forward scatter of erythrocytes following exposure for 48 hours to Ringer solution without (grey area) and with (black line) presence of $60 \mu \mathrm{g} / \mathrm{ml}$ Taurolidine. B. Arithmetic means \pm SEM $(n=15)$ of the erythrocyte forward scatter (FSC) following incubation

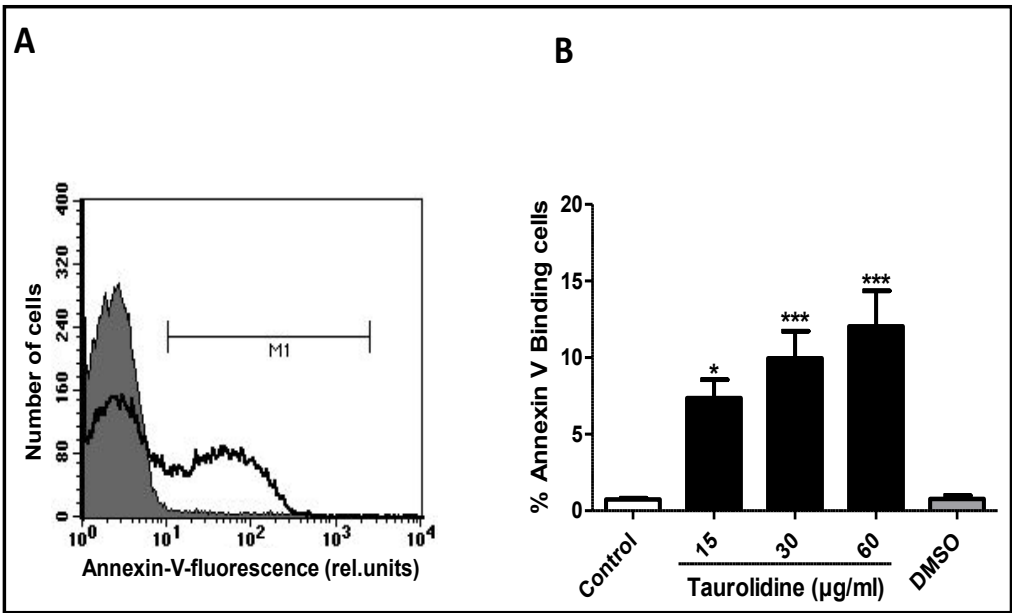
for 48 hours to Ringer solution without (white bar) or with (black bars) Taurolidine $(15,30,60 \mu \mathrm{g} / \mathrm{ml}) .{ }^{* *}(\mathrm{p}<0.01){ }^{* * *}(\mathrm{p}<0.001)$ indicates significant difference from the absence of Taurolidine (ANOVA).

Fig. 3. Effect of Taurolidine on cytosolic $\mathrm{Ca}^{2+}$. A. Original histogram of Fluo3fluorescence reflecting cytosolic $\mathrm{Ca}^{2+}$ activity of erythrocytes following exposure for 48 hours to Ringer solution without (grey area) and with (black line) presence of $60 \mu \mathrm{g} / \mathrm{ml}$ Taurolidine. B. Arithmetic means \pm SEM $(n=15)$ of Fluo3-fluorescence reflecting cytosolic $\mathrm{Ca}^{2+}$ activity of

A B

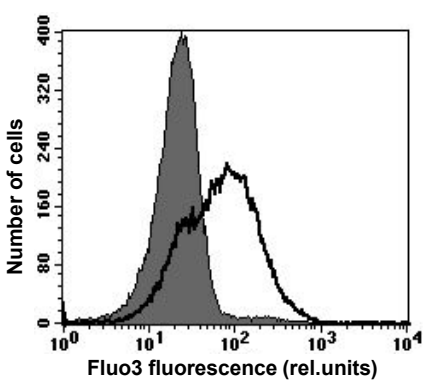

B
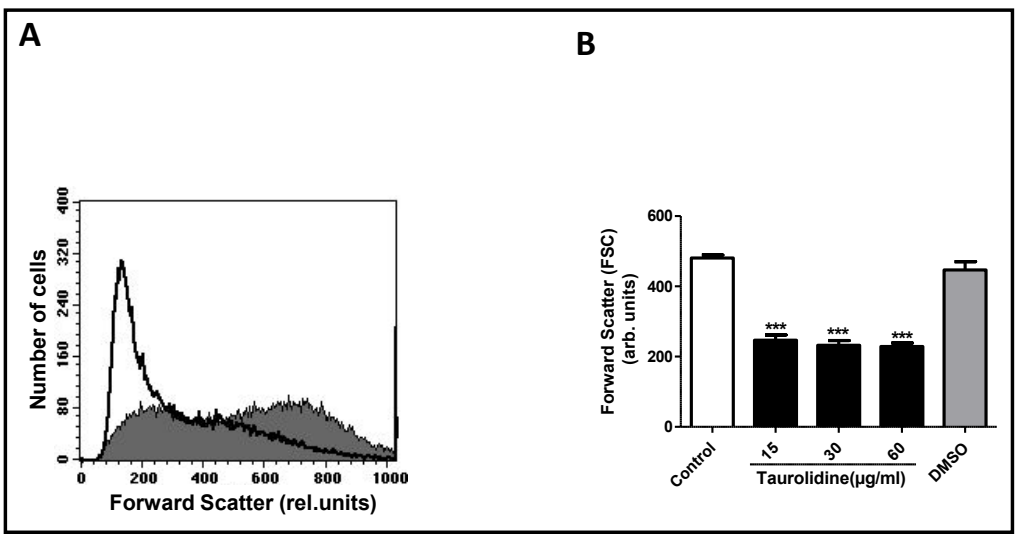


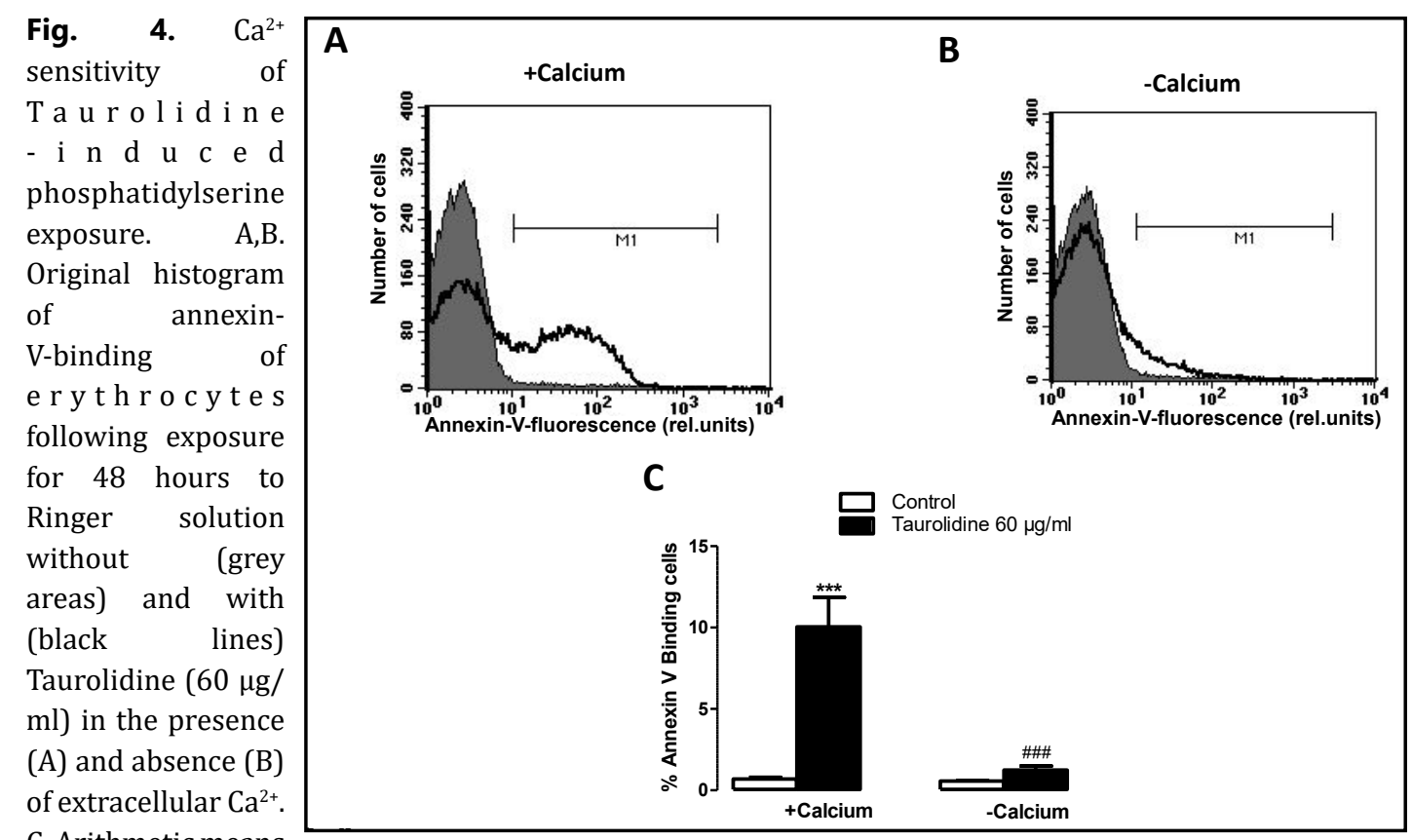

C. Arithmetic means

\pm SEM $(n=11)$ of annexin-V-binding of erythrocytes after a 48 hours treatment with Ringer solution without (white bars) or with Taurolidine $(60 \mu \mathrm{g} / \mathrm{ml})$ in the presence (left bars, $\left.+\mathrm{Ca}^{2+}\right)$ and absence (right bars, $\left.\mathrm{Ca}^{2+}\right)$ of $\mathrm{Ca}^{2+} .{ }^{* * *}(\mathrm{p}<0.001)$ indicates significant difference from the absence of Taurolidine, \#\#\#(p<0.001) indicates significant difference from the presence of $\mathrm{Ca}^{2+}$ (ANOVA).

the Fluo3-fluorescence at all Taurolidine concentrations tested.

A next series of experiments explored whether the Taurolidineinduced translocation of phosphatidylserine required entry of extracellular $\mathrm{Ca}^{2+}$. To this end, erythrocytes were incubated for 48 hours in the absence or presence of $60 \mu \mathrm{g} / \mathrm{ml}$ Taurolidine in the presence or nominal absence of extracellular $\mathrm{Ca}^{2+}$. As illustrated in Fig. 4, removal of extracellular $\mathrm{Ca}^{2+}$ significantly blunted the effect of taurolidine on annexin-V-binding. In the absence of extracellular $\mathrm{Ca}^{2+}$, Taurolidine tended to increase the percentage of annexin-V-binding erythrocytes, an effect, however, not reaching statistical significance (Fig. 4). Thus, Taurolidine-induced cell membrane scrambling was in large part triggered by entry of extracellular $\mathrm{Ca}^{2+}$.

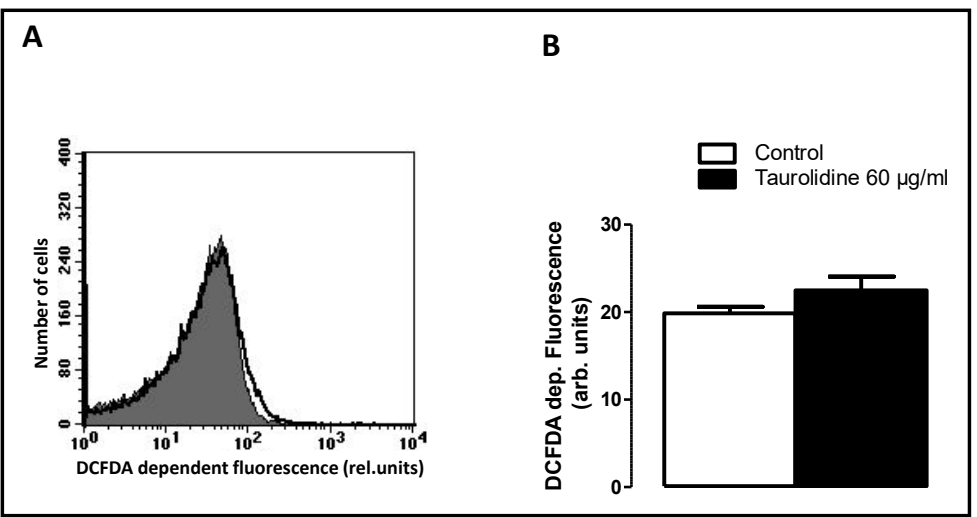

Fig. 5. Effect of Taurolidine on reactive oxygen species (ROS). A. Original histogram of 2',7'-dichlorodihydrofluorescein (DCF) fluorescence reflecting ROS of erythrocytes following exposure for 48 hours to Ringer solution without (grey area) and with (black line) presence of $60 \mu \mathrm{g} / \mathrm{ml}$ Taurolidine. B. Arithmetic means \pm SEM $(n=15)$ of DCF fluorescence in erythrocytes following incubation for 48 hours to Ringer solution without (white bar) or with (black bars) Taurolidine $(60 \mu \mathrm{g} / \mathrm{ml})$. For comparison, the effect of the solvent DMSO (grey bar). 
Fig. 6. Effect of Taurolidine on ceramide abundance. A. Original histogram of ceramide abundance in erythrocytes following exposure for 48 hours to Ringer solution with solvent DMSO (grey area) and with presence of Taurolidine (60 $\mu \mathrm{g} / \mathrm{ml}$ ) (black line). B. Arithmetic means \pm SEM (n $=5$ ) of ceramide abundance in erythrocytes following incubation for 24 hours to Ringer solution without (white bar) or with (black bars) presence of Taurolidine $(60 \mu \mathrm{g} / \mathrm{ml}) .{ }^{* * *}(\mathrm{p}<0.001)$ indicates significant difference from the absence of Taurolidine (ANOVA).

$\mathrm{Ca}^{2+}$ entry and eryptosis are known to be stimulated by oxidative stress. Reactive oxygen species (ROS) was thus quantified utilizing $2^{\prime}, 7^{\prime}$-dichlorodihydrofluorescein (DCF) diacetate. As a result, DCF fluorescence was similar after 48 hours incubation without and with $60 \mu \mathrm{g} /$ ml Taurolidine (Fig. 5).

A further known stimulator of eryptosis is ceramide. Ceramide abundance at the erythrocyte surface was thus quantified utilizing specific antibodies. As shown in Fig. 6, a 48 hours exposure to $60 \mu \mathrm{g} / \mathrm{ml}$ Taurolidine significantly increased the ceramide abundance.

\section{Discussion}

The present observations uncover a novel effect of Taurolidine, i.e. the stimulation of eryptosis, the suicidal erythrocyte death. Treatment of erythrocytes with Taurolidine was followed by cell membrane scrambling with phosphatidylserine translocation to the erythrocyte surface. Taurolidine further triggered cell shrinkage, another hallmark of eryptosis [58]. The concentration required for stimulation of eryptosis was similar to those required to trigger apoptosis of tumor cells [114-117] and to those achieved in patients [118].

The effect of Taurolidine on cell membrane scrambling and cell shrinkage was paralleled by a significant increase of Fluo3-fluorescence reflecting cytosolic $\mathrm{Ca}^{2+}$ activity. The effect of Taurolidine on cell membrane scrambling was in large part dependent on $\mathrm{Ca}^{2+}$ entry from the extracellular space. Accordingly, removal of extracellular $\mathrm{Ca}^{2+}$ virtually abrogated the Taurolidine induced eryptosis. Taurolidine-induced cell shrinkage could result from $\mathrm{Ca}^{2+}$ entry, activation of $\mathrm{Ca}^{2+}$ sensitive $\mathrm{K}^{+}$channels, $\mathrm{K}^{+}$exit, cell membrane hyperpolarization, $\mathrm{Cl}^{-}$exit and thus cellular loss of $\mathrm{KCl}$ with water [58].

Taurolidine-induced cell membrane scrambling and cell shrinkage were paralleled by increased abundance of ceramide which is known to sensitize erythrocytes for the scrambling effect of $\mathrm{Ca}^{2+}$ [58]. Apparently, Taurolidine has only little effect on oxidative stress.

Eryptotic erythrocytes are rapidly cleared from circulating blood [33] and the physiological function of eryptosis is the removal of defective erythrocytes prior to hemolysis with release of hemoglobin, which passes the renal glomerular filter and precipitates in the acidic lumen of renal tubules thus occluding the affected nephrons with subsequent renal failure [119]. Hemoglobin could further affect microcirculation [120].

The loss of erythrocytes following clearance of phosphatidylserine exposing erythrocytes from circulating blood may, however, surpass the formation of new erythrocytes by erythropoiesis and thus lead to anaemia [33]. Phosphatidylserine exposing erythrocytes may further adhere to endothelial cells of the vascular wall [121], stimulate blood clotting and trigger thrombosis [122-124], thus impairing microcirculation [122, 125-129]. 


\section{Cellular Physiology

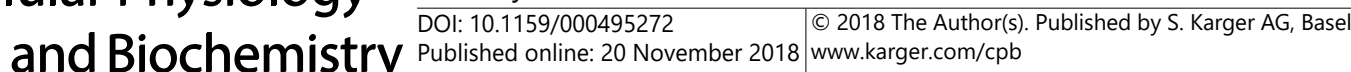

Fink et al.: Taurolidine-Induced Eryptosis

\section{Conclusion}

In conclusion, Taurolidine stimulates eryptosis with cell membrane scrambling and cell shrinkage, an effect paralleled by and in large part due to $\mathrm{Ca}^{2+}$ entry and ceramide.

\section{Acknowledgements}

The authors acknowledge the meticulous preparation of the manuscript by Lejla Subasic. The study was supported by the Deutsche Forschungsgemeinschaft.

\section{Disclosure Statement}

The authors have no competing interests.

\section{References}

1 Pirracchio L, Joos A, Luder N, Sculean A, Eick S: Activity of taurolidine gels on ex vivo periodontal biofilm. Clin Oral Investig 2017; DOI:10.1007/s00784-017-2297-6.

- Kurt N, Sikar HE, Kaptanoglu L, Kucuk HF: Separate and synergistic effects of taurolidine and icodextrin in intra-abdominal adhesion prevention. Ulus Travma Acil Cerrahi Derg 2017;23:377-382.

- Z Zeriouh M, Sabashnikov A, Patil NP, Schmack B, Zych B, Mohite PN, Garcia Saez D, Koch A, Mansur A, Soresi S, Weymann A, Marczin N, Wahlers T, De Robertis F, Simon AR, Popov AF: Use of taurolidine in lung transplantation for cystic fibrosis and impact on bacterial colonization. Eur J Cardiothorac Surg 2018;53:603-609.

4 Wormhoudt T, Seguin B, Bemis DA, Hyatt D: Taurolidine susceptibility of methicillin-resistant Staphylococcus pseudintermedius isolates. J Vet Diagn Invest 2017;29:910-911.

5 Ulusoy AT, Kalyoncuoglu E, Reis A, Cehreli ZC: Antibacterial effect of N-acetylcysteine and taurolidine on planktonic and biofilm forms of Enterococcus faecalis. Dent Traumatol 2016;32:212-218.

6 Eick S, Gloor N, Puls C, Zumbrunn J, Sculean A: In vitro activity of taurolidine gel on bacteria associated with periodontitis. Clin Oral Investig 2016;20:597-606.

7 Zollinger L, Schnyder S, Nietzsche S, Sculean A, Eick S: In-vitro activity of taurolidine on single species and a multispecies population associated with periodontitis. Anaerobe 2015;32:18-23.

8 John G, Schwarz F, Becker J: Taurolidine as an effective and biocompatible additive for plaque-removing techniques on implant surfaces. Clin Oral Investig 2015;19:1069-1077.

-9 Kavosi Z, Sarikhani Khorrami M, Keshavarz K, Jafari A, Hashemi Meshkini A, Safaei HR, Nikfar S: Is Taurolidine-citrate an effective and cost-effective hemodialysis catheter lock solution? A systematic review and cost- effectiveness analysis. Med J Islam Repub Iran 2016;30:347.

10 Liu H, Liu H, Deng J, Chen L, Yuan L, Wu Y: Preventing catheter-related bacteremia with taurolidine-citrate catheter locks: a systematic review and meta-analysis. Blood Purif 2014;37:179-187.

11 Liu Y, Zhang AQ, Cao L, Xia HT, Ma JJ: Taurolidine lock solutions for the prevention of catheter-related bloodstream infections: a systematic review and meta-analysis of randomized controlled trials. PLoS One 2013;8:e79417.

12 Chu HP, Brind J, Tomar R, Hill S: Significant reduction in central venous catheter-related bloodstream infections in children on HPN after starting treatment with taurolidine line lock. J Pediatr Gastroenterol Nutr 2012;55:403-407.

13 Bradshaw JH, Puntis JW: Taurolidine and catheter-related bloodstream infection: a systematic review of the literature. J Pediatr Gastroenterol Nutr 2008;47:179-186.

$\checkmark 14$ Gudiol C, Nicolae S, Royo-Cebrecos C, Aguilar-Guisado M, Montero I, Martin-Gandul C, Perayre M, Berbel D, Encuentra M, Arnan M, Cisneros-Herreros JM, Carratala J: Administration of taurolidine-citrate lock solution for prevention of central venous catheter infection in adult neutropenic haematological patients: a randomised, double-blinded, placebo-controlled trial (TAURCAT). Trials 2018;19:264. 


\section{Cellular Physiology Cell Physiol Biochem 2018;51:501-512 \begin{tabular}{l|l|l} 
and Biochemistry Published online: 20 November 2018 & $\begin{array}{l}\text { @ } 2018 \text { The Author(s). Published by S. Karger AG, Basel } \\
\text { www.karger.com/cpb }\end{array}$ \\
\hline
\end{tabular}}

15 Labriola L, Jadoul M: Taurolidine-based lock solutions for hemodialysis catheters: the enthusiasm should be tempered. Kidney Int 2018;93:1015-1016.

16 Lambe C, Poisson C, Talbotec C, Goulet O: Strategies to Reduce Catheter-Related Bloodstream Infections in Pediatric Patients Receiving Home Parenteral Nutrition: The Efficacy of Taurolidine-Citrate ProphylacticLocking. JPEN J Parenter Enteral Nutr 2018; DOI:10.1002/jpen.1043.

$\checkmark 17$ Reidenberg BE, Wanner C, Polsky B, Castanheira M, Shelip A, Stalleicken D, Pfaffle AE: Postmarketing experience with Neutrolin(R) (taurolidine, heparin, calcium citrate) catheter lock solution in hemodialysis patients. Eur J Clin Microbiol Infect Dis 2018;37:661-663.

-18 Al-Ali F, Hamdy AF, Hamad A, Elsayed M, Zafar Iqbal Z, Elsayed A, Ibrahim R, Tolba H, Buanan H, Fawzy A: Safety and efficacy of taurolidine/urokinase versus taurolidine/heparin as a tunneled catheter lock solution in hemodialysis patients: a prospective, randomized, controlled study. Nephrol Dial Transplant 2017; DOI:10.1093/ndt/gfx187.

19 Winnicki W, Herkner H, Lorenz M, Handisurya A, Kikic Z, Bielesz B, Schairer B, Reiter T, Eskandary F, Sunder-Plassmann G, Sengoelge G: Taurolidine-based catheter lock regimen significantly reduces overall costs, infection, and dysfunction rates of tunneled hemodialysis catheters. Kidney Int 2018;93:753-760.

-20 Tribler S, Brandt CF, Petersen AH, Petersen JH, Fuglsang KA, Staun M, Broebech P, Moser CE, Jeppesen PB: Taurolidine-citrate-heparin lock reduces catheter-related bloodstream infections in intestinal failure patients dependent on home parenteral support: a randomized, placebo-controlled trial. Am J Clin Nutr 2017;106:839-848.

21 Longo R, Llorens M, Goetz C, Platini C, Eid N, Sellies J, Ouamara N, Quetin P: Taurolidine/Citrate Lock Therapy for Primary Prevention of Catheter-Related Infections in Cancer Patients: Results of a Prospective, Randomized, Phase IV Trial (ATAPAC). Oncology 2017;93:99-105.

22 Hulshof EC, Hanff LM, Olieman J, de Vette S, Driessen GJ, Meeussen C, Escher JC: Taurolidine in Pediatric Home Parenteral Nutrition Patients. Pediatr Infect Dis J 2017;36:233-235.

-23 Olthof ED, Broekman MM, Wanten GJ: Do we know the benefits of a taurolidine lock in adult home parenteral nutrition patients with a low infection rate? JPEN J Parenter Enteral Nutr 2015;39:385.

-24 Olthof ED, Versleijen MW, Huisman-de Waal G, Feuth T, Kievit W, Wanten GJ: Taurolidine lock is superior to heparin lock in the prevention of catheter related bloodstream infections and occlusions. PLoS One 2014;9:e111216.

25 Harati K, Emmelmann S, Behr B, Goertz O, Hirsch T, Kapalschinski N, Kolbenschlag J, Stricker I, Tannapfel A, Lehnhardt M, Daigeler A: Evaluation of the safety and efficacy of TRAIL and taurolidine use on human fibrosarcoma xenografts in vivo. Oncol Lett 2016;11:1955-1961.

-26 Eschenburg G, Luckert C, Reinshagen K, Bergholz R: Taurolidine cooperates with antineoplastic drugs in neuroblastoma cells. Genes Cancer 2014;5:460-469.

27 Hotz B, Erben U, Arndt M, Buhr HJ, Hotz HG: Taurolidine induces epithelial-mesenchymal transition via up-regulation of the transcription factor Snail in human pancreatic cancer cell lines. Int J Colorectal Dis 2014;29:1339-1348.

28 Mohler H, Pfirrmann RW, Frei K: Redox-directed cancer therapeutics: Taurolidine and Piperlongumine as broadly effective antineoplastic agents (review). Int J Oncol 2014;45:1329-1336.

29 Neary PM, Hallihan P, Wang JH, Pfirrmann RW, Bouchier-Hayes DJ, Redmond HP: The evolving role of taurolidine in cancer therapy. Ann Surg Oncol 2010;17:1135-1143.

-30 Jacobi CA, Menenakos C, Braumann C: Taurolidine--a new drug with anti-tumor and anti-angiogenic effects. Anticancer Drugs 2005;16:917-921.

-31 Fahrner R, Moller A, Press AT, Kortgen A, Kiehntopf M, Rauchfuss F, Settmacher U, Mosig AS: Short-term treatment with taurolidine is associated with liver injury. BMC Pharmacol Toxicol 2017;18:61.

-32 Kichko TI, Pfirrmann RW, Reeh PW: Taurolidine and congeners activate hTRPA1 but not hTRPV1 channels and stimulate CGRP release from mouse tracheal sensory nerves. Pharmacol Res Perspect 2016;4:e00204.

33 Lang E, Lang F: Mechanisms and pathophysiological significance of eryptosis, the suicidal erythrocyte death. Semin Cell Dev Biol 2015;39:35-42.

34 Gusev GP, Govekar R, Gadewal N, Agalakova NI: Understanding quasi-apoptosis of the most numerous enucleated components of blood needs detailed molecular autopsy. Ageing Res Rev 2017;35:46-62.

-35 Qadri SM, Bissinger R, Solh Z, Oldenborg PA: Eryptosis in health and disease: A paradigm shift towards understanding the (patho)physiological implications of programmed cell death of erythrocytes. Blood Rev 2017;31:349-361.

-36 Lang PA, Kaiser S, Myssina S, Wieder T, Lang F, Huber SM: Role of Ca2+-activated K+ channels in human erythrocyte apoptosis. Am J Physiol Cell Physiol 2003;285:C1553-C1560. 


\section{Cellular Physiology Cell Physiol Biochem 2018;51:501-512 \begin{tabular}{l|l|l} 
and Biochemistry Published onlIne: ZU November 2018 & $\begin{array}{l}\text { ( 2018 The Author(s). Published by S. Karger AG, Basel } \\
\text { www.karger.com/cpb }\end{array}$ \\
\hline
\end{tabular}}

Fink et al.: Taurolidine-Induced Eryptosis

-37 Lau IP, Chen H, Wang J, Ong HC, Leung KC, Ho HP, Kong SK: In vitro effect of CTAB- and PEG-coated gold nanorods on the induction of eryptosis/erythroptosis in human erythrocytes. Nanotoxicology 2012;6:847856.

-38 Maellaro E, Leoncini S, Moretti D, Del Bello B, Tanganelli I, De Felice C, Ciccoli L: Erythrocyte caspase-3 activation and oxidative imbalance in erythrocytes and in plasma of type 2 diabetic patients. Acta Diabetol 2013;50:489-495.

-39 Bissinger R, Lang E, Ghashghaeinia M, Singh Y, Zelenak C, Fehrenbacher B, Honisch S, Chen H, Fakhri H, Umbach AT, Liu G, Rexhepaj R, Liu G, Schaller M, Mack AF, Lupescu A, Birnbaumer L, Lang F, Qadri SM: Blunted apoptosis of erythrocytes in mice deficient in the heterotrimeric G-protein subunit Galphai2. Sci Rep 2016;6:30925.

40 Lang E, Bissinger R, Fajol A, Salker MS, Singh Y, Zelenak C, Ghashghaeinia M, Gu S, Jilani K, Lupescu A, Reyskens KM, Ackermann TF, Foller M, Schleicher E, Sheffield WP, Arthur JS, Lang F, Qadri SM: Accelerated apoptotic death and in vivo turnover of erythrocytes in mice lacking functional mitogen- and stressactivated kinase MSK1/2. Sci Rep 2015;5:17316.

41 Qadri SM, Chen D, Schubert P, Perruzza DL, Bhakta V, Devine DV, Sheffield WP: Pathogen inactivation by riboflavin and ultraviolet light illumination accelerates the red blood cell storage lesion and promotes eryptosis. Transfusion 2017;57:661-673.

42 Qadri SM, Chen D, Schubert P, Devine DV, Sheffield WP: Early gamma-irradiation and subsequent storage of red cells in SAG-M additive solution potentiate energy imbalance, microvesiculation and susceptibility to stress-induced apoptotic cell death. Vox Sang 2017;112:480-483.

43 Al Mamun Bhuyan A, Bissinger R, Cao H, Lang F: Triggering of Suicidal Erythrocyte Death by Bexarotene. Cell Physiol Biochem 2016;40:1239-1251.

44 Macczak A, Cyrkler M, Bukowska B, Michalowicz J: Eryptosis-inducing activity of bisphenol A and its analogs in human red blood cells (in vitro study). J Hazard Mater 2016;307:328-335.

$>45$ Officioso A, Manna C, Alzoubi K, Lang F: Bromfenvinphos induced suicidal death of human erythrocytes. Pestic Biochem Physiol 2016;126:58-63.

46 Qadri SM, Donkor DA, Bhakta V, Eltringham-Smith LJ, Dwivedi DJ, Moore JC, Pepler L, Ivetic N, Nazi I, FoxRobichaud AE, Liaw PC, Sheffield WP: Phosphatidylserine externalization and procoagulant activation of erythrocytes induced by Pseudomonas aeruginosa virulence factor pyocyanin. J Cell Mol Med 2016; DOI:10.1111/jcmm.12778

47 Zierle J, Bissinger R, Bouguerra G, Abbes S, Lang F: Triggering of Suicidal Erythrocyte Death by Regorafenib. Cell Physiol Biochem 2016;38:160-172.

48 Pagano M, Faggio C: The use of erythrocyte fragility to assess xenobiotic cytotoxicity. Cell Biochem Funct 2015;33:351-355.

49 Al Mamun Bhuyan A, Signoretto E, Bissinger R, Lang F: Enhanced Eryptosis Following Exposure to Dolutegravir. Cell Physiol Biochem 2016;39:639-650.

50 Al Mamun Bhuyan A, Signoretto E, Lang F: Triggering of Suicidal Erythrocyte Death by Psammaplin A. Cell Physiol Biochem 2016;39:908-918.

-51 Almasry M, Jemaa M, Mischitelli M, Faggio C, Lang F: Stimulation of Suicidal Erythrocyte Death by Phosphatase Inhibitor Calyculin A. Cell Physiol Biochem 2016;40:163-171.

52 Bissinger R, Bhuyan AA, Signoretto E, Lang F: Stimulating Effect of Elvitegravir on Suicidal Erythrocyte Death. Cell Physiol Biochem 2016;38:1111-1120.

53 Egler J, Zierle J, Lang F: Stimulating Effect of Manumycin A on Suicidal Erythrocyte Death. Cell Physiol Biochem 2016;38:1147-1156.

54 Mischitelli M, Jemaa M, Almasry M, Faggio C, Lang F: Stimulation of Erythrocyte Cell Membrane Scrambling by Quinine. Cell Physiol Biochem 2016;40:657-667.

55 Mischitelli M, Jemaa M, Almasry M, Faggio C, Lang F: Stimulation of Suicidal Erythrocyte Death by Rottlerin. Cell Physiol Biochem 2016;40:558-566.

-56 Mischitelli M, Jemaa M, Almasry M, Faggio C, Lang F: Triggering of Suicidal Erythrocyte Death by Fascaplysin. Cell Physiol Biochem 2016;39:1638-1647.

57 Mischitelli M, Jemaa M, Almasry M, Faggio C, Lang F: Ca2+ Entry, Oxidative Stress, Ceramide and Suicidal Erythrocyte Death Following Diosgenin Treatment. Cell Physiol Biochem 2016;39:1626-1637.

58 Mischitelli M, Jemaa M, Almasry M, Faggio C, Lang F: Triggering of Erythrocyte Cell Membrane Scrambling by Emodin. Cell Physiol Biochem 2016;40:91-103.

59 Peter T, Bissinger R, Lang F: Stimulation of Eryptosis by Caspofungin. Cell Physiol Biochem 2016;39:939949. 


\section{Cellular Physiology Cell Physiol Biochem 2018;51:501-512

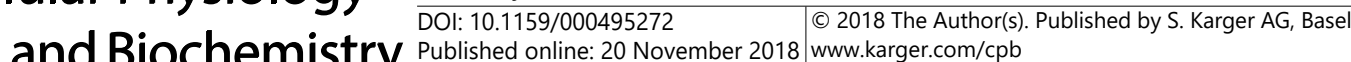

60 Peter T, Bissinger R, Liu G, Lang F: Anidulafungin-Induced Suicidal Erythrocyte Death. Cell Physiol Biochem 2016;38:2272-2284.

-61 Peter T, Bissinger R, Signoretto E, Mack AF, Lang F: Micafungin-Induced Suicidal Erythrocyte Death. Cell Physiol Biochem 2016;39:584-595.

62 Pretorius E, du Plooy JN, Bester J: A Comprehensive Review on Eryptosis. Cell Physiol Biochem 2016;39:1977-2000.

63 Shan F, Yang R, Ji T, Jiao F: Vitamin C Inhibits Aggravated Eryptosis by Hydrogen Peroxide in Glucose-6Phosphated Dehydrogenase Deficiency. Cell Physiol Biochem 2016;39:1453-1462.

-64 Signoretto E, Honisch S, Briglia M, Faggio C, Castagna M, Lang F: Nocodazole Induced Suicidal Death of Human Erythrocytes. Cell Physiol Biochem 2016;38:379-392.

65 Signoretto E, Laufer SA, Lang F: Stimulating Effect of Sclareol on Suicidal Death of Human Erythrocytes. Cell Physiol Biochem 2016;39:554-564.

66 Signoretto E, Zierle J, Bissinger R, Castagna M, Bossi E, Lang F: Triggering of Suicidal Erythrocyte Death by Pazopanib. Cell Physiol Biochem 2016;38:926-938.

67 Wesseling MC, Wagner-Britz L, Huppert H, Hanf B, Hertz L, Nguyen DB, Bernhardt I: Phosphatidylserine Exposure in Human Red Blood Cells Depending on Cell Age. Cell Physiol Biochem 2016;38:1376-1390.

68 Zierle J, Bissinger R, Lang F: Inhibition by Teriflunomide of Erythrocyte Cell Membrane Scrambling Following Energy Depletion, Oxidative Stress and Ionomycin. Cell Physiol Biochem 2016;39:1877-1890.

69 Al Mamun Bhuyan A, Bissinger R, Cao H, Lang F: Triggering of Suicidal Erythrocyte Death by Bexarotene. Cell Physiol Biochem 2016;40:1239-1251.

70 Farag MR, Alagawany M: Erythrocytes as a biological model for screening of xenobiotics toxicity. Chem Biol Interact 2018;279:73-83.

71 Ray RR: Adverse hematological effects of hexavalent chromium: an overview. Interdiscip Toxicol 2016;9:5565.

72 Al Mamun Bhuyan A, Bissinger R, Cao H, Lang F: Triggering of Suicidal Erythrocyte Death by Exemestane. Cell Physiol Biochem 2017;42:1-12.

73 Swanepoel AC, Emmerson 0, Pretorius E: Effect of Progesterone and Synthetic Progestins on Whole Blood Clot Formation and Erythrocyte Structure. Microsc Microanal 2017;23:607-617.

74 Swanepoel AC, Emmerson O, Pretorius E: The Effect of Endogenous and Synthetic Estrogens on Whole Blood Clot Formation and Erythrocyte Structure. Microsc Microanal 2017;23:599-606.

75 Egler J, Lang F: Triggering of Eryptosis, the Suicidal Erythrocyte Death, by Perifosine. Cell Physiol Biochem 2017;41:2534-2544.

-76 Abed M, Alzoubi K, Lang F, Al Mamun Bhuayn A: Stimulation of Phospholipid Scrambling of the Erythrocyte Membrane by 9-Cis-Retinoic Acid. Cell Physiol Biochem 2017;41:543-554.

77 Abed M, Thiel C, Towhid ST, Alzoubi K, Honisch S, Lang F, Konigsrainer A: Stimulation of Erythrocyte Cell Membrane Scrambling by C-Reactive Protein. Cell Physiol Biochem 2017;41:806-818.

78 Mischitelli M, Jemaaa M, Fezai M, Almasry M, Lang F, Faggio C: Stimulation of Erythrocyte Cell Membrane Scrambling by Adarotene. Cell Physiol Biochem 2017;41:519-529.

-79 Al Mamun Bhuyan A, Nguyen MT, Bissinger R, Gotz F, Lang F: Lipopeptide-Induced Suicidal Erythrocyte Death Correlates with the Degree of Acylation. Cell Physiol Biochem 2017;41:296-309.

-80 Al Mamun Bhuyan A, Wagner T, Cao H, Lang F: Triggering of Suicidal Erythrocyte Death by Gefitinib. Cell Physiol Biochem 2017;41:1697-1708.

81 Almasry M, Jemaa M, Mischitelli M, Lang F, Faggio C: Camalexin-Induced Cell Membrane Scrambling and Cell Shrinkage in Human Erythrocytes. Cell Physiol Biochem 2017;41:731-741.

82 Farag MR, Alagawany M, Tufarelli V: In vitro antioxidant activities of resveratrol, cinnamaldehyde and their synergistic effect against cyadox-induced cytotoxicity in rabbit erythrocytes. Drug Chem Toxicol 2017;40:196-205.

83 Al Mamun Bhuyan A, Nussle S, Cao H, Zhang S, Lang F: Simvastatin, a Novel Stimulator of Eryptosis, the Suicidal Erythrocyte Death. Cell Physiol Biochem 2017;43:492-506.

84 Al Mamun Bhuyan A, Cao H, Lang F: Triggering of Eryptosis, the Suicidal Erythrocyte Death by Mammalian Target of Rapamycin (mTOR) inhibitor Temsirolimus. Cell Physiol Biochem 2017;42:1575-1591.

85 Ghashghaeinia M, Wesseling MC, Ramos E, Petkova-Kirova P, Waibel S, Lang E, Bissinger R, Alzoubi K, Edelmann B, Hosseinzadeh Z, Dreischer P, Shahvaroughi-Farahani A, Mrowietz U, Koberle M, Kaestner L, Bernhardt I, Martinez-Ruiz A, Wieder T, Lang F: Trifluoperazine-Induced Suicidal Erythrocyte Death and S-Nitrosylation Inhibition, Reversed by the Nitric Oxide Donor Sodium Nitroprusside. Cell Physiol Biochem 2017;42:1985-1998. 


\section{Cellular Physiology Cell Physiol Biochem 2018;51:501-512

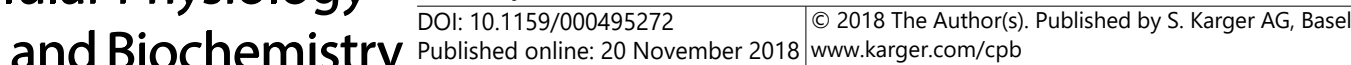

-86 Al Mamun Bhuyan A, Signoretto E, Bissinger R, Lang F: Stimulation of Suicidal Erythrocyte Death by Ceritinib-Treatment of Human Erythrocytes. Cell Physiol Biochem 2016;40:1129-1140.

87 Jemaa M, Mischitelli M, Fezai M, Almasry M, Faggio C, Lang F: Stimulation of Suicidal Erythrocyte Death by the CDC25 Inhibitor NSC-95397. Cell Physiol Biochem 2016;40:597-607.

-88 Jemaa M, Fezai M, Lang F: Inhibition of Suicidal Erythrocyte Death by Reversine. Cell Physiol Biochem 2017;41:2363-2373.

-89 Al Mamun Bhuyan A, Bissinger R, Cao H, Lang F: Inhibition of Erythrocyte Cell Membrane Scrambling by ASP3026. Cell Physiol Biochem 2017;43:507-517.

$\$ 90$ Al Mamun Bhuyan A, Ashiqul Haque AKM, Sahu I, Cao H, Kormann MSD, Lang F: Inhibition of Suicidal Erythrocyte Death by Volasertib. Cell Physiol Biochem 2017;43:1472-1486.

$\$ 91$ Jagadish S, Hemshekhar M, NaveenKumar SK, Sharath Kumar KS, Sundaram MS, Basappa, Girish KS, Rangappa KS: Novel oxolane derivative DMTD mitigates high glucose-induced erythrocyte apoptosis by regulating oxidative stress. Toxicol Appl Pharmacol 2017;334:167-179.

-92 Abed M, Artunc F, Alzoubi K, Honisch S, Baumann D, Foller M, Lang F: Suicidal erythrocyte death in endstage renal disease. J Mol Med (Berl) 2014;92:871-879.

$\$ 93$ Polak-Jonkisz D, Purzyc L: Ca(2+) influx versus efflux during eryptosis in uremic erythrocytes. Blood Purif 2012;34:209-210; author reply 210.

$\$ 94$ Calderon-Salinas JV, Munoz-Reyes EG, Guerrero-Romero JF, Rodriguez-Moran M, Bracho-Riquelme RL, Carrera-Gracia MA, Quintanar-Escorza MA: Eryptosis and oxidative damage in type 2 diabetic mellitus patients with chronic kidney disease. Mol Cell Biochem 2011;357:171-179.

$\$ 95$ Bissinger R, Artunc F, Qadri SM, Lang F: Reduced Erythrocyte Survival in Uremic Patients Under Hemodialysis or Peritoneal Dialysis. Kidney Blood Press Res 2016;41:966-977.

$\$ 96$ Meyring-Wosten A, Kuntsevich V, Campos I, Williams S, Ma J, Patel S, Ornillo C, Thijssen S, Kotanko P: Erythrocyte Sodium Sensitivity and Eryptosis in Chronic Hemodialysis Patients. Kidney Blood Press Res 2017;42:314-326.

-97 Lang F, Bissinger R, Abed M, Artunc F: Eryptosis - the Neglected Cause of Anemia in End Stage Renal Disease. Kidney Blood Press Res 2017;42:749-760.

-98 Lang PA, Beringer O, Nicolay JP, Amon O, Kempe DS, Hermle T, Attanasio P, Akel A, Schafer R, Friedrich B, Risler T, Baur M, Olbricht CJ, Zimmerhackl LB, Zipfel PF, Wieder T, Lang F: Suicidal death of erythrocytes in recurrent hemolytic uremic syndrome. J Mol Med (Berl) 2006;84:378-388.

99 Bartolmas T, Mayer B, Balola AH, Salama A: Eryptosis in autoimmune haemolytic anaemia. Eur J Haematol 2018;100:36-44.

100 Pinzon-Diaz CE, Calderon-Salinas JV, Rosas-Flores MM, Hernandez G, Lopez-Betancourt A, QuintanarEscorza MA: Eryptosis and oxidative damage in hypertensive and dyslipidemic patients. Mol Cell Biochem 2018;440:105-113.

101 Lang E, Gatidis S, Freise NF, Bock H, Kubitz R, Lauermann C, Orth HM, Klindt C, Schuier M, Keitel V, Reich M, Liu G, Schmidt S, Xu HC, Qadri SM, Herebian D, Pandyra AA, Mayatepek E, Gulbins E, Lang F, et al.: Conjugated bilirubin triggers anemia by inducing erythrocyte death. Hepatology 2015;61:275-284.

102 Bissinger R, Schumacher C, Qadri SM, Honisch S, Malik A, Gotz F, Kopp HG, Lang F: Enhanced eryptosis contributes to anemia in lung cancer patients. Oncotarget 2016;7:14002-14014.

103 Qadri SM, Mahmud H, Lang E, Gu S, Bobbala D, Zelenak C, Jilani K, Siegfried A, Foller M, Lang F: Enhanced suicidal erythrocyte death in mice carrying a loss-of-function mutation of the adenomatous polyposis coli gene. J Cell Mol Med 2012;16:1085-1093.

104 Lang E, Bissinger R, Qadri SM, Lang F: Suicidal death of erythrocytes in cancer and its chemotherapy: A potential target in the treatment of tumor-associated anemia. Int J Cancer 2017;141:1522-1528.

-105 Bissinger R, Kempe-Teufel DS, Honisch S, Qadri SM, Randrianarisoa E, Haring HU, Henes J, Lang F: Stimulated Suicidal Erythrocyte Death in Arteritis. Cell Physiol Biochem 2016;39:1068-1077.

106 Jiang P, Bian M, Ma W, Liu C, Yang P, Zhu B, Xu Y, Zheng M, Qiao J, Shuai Z, Zhou X, Huang D: Eryptosis as an Underlying Mechanism in Systemic Lupus Erythematosus-Related Anemia. Cell Physiol Biochem 2016;40:1391-1400.

107 Lang PA, Schenck M, Nicolay JP, Becker JU, Kempe DS, Lupescu A, Koka S, Eisele K, Klarl BA, Rubben H, Schmid KW, Mann K, Hildenbrand S, Hefter H, Huber SM, Wieder T, Erhardt A, Haussinger D, Gulbins E, Lang F: Liver cell death and anemia in Wilson disease involve acid sphingomyelinase and ceramide. Nat Med 2007;13:164-170. 


\section{Cellular Physiology Cell Physiol Biochem 2018;51:501-512

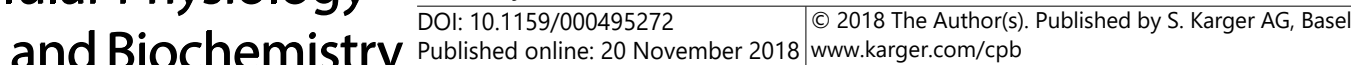

108 Zhong H, Wake H, Liu K, Gao Y, Teshigawara K, Sakaguchi M, Mori S, Nishibori M: Effects of Histidine-rich glycoprotein on erythrocyte aggregation and hemolysis: Implications for a role under septic conditions. J Pharmacol Sci 2018;136:97-106.

109 Fallatah 0, Georges E: Apigenin-induced ABCC1-mediated efflux of glutathione from mature erythrocytes inhibits the proliferation of Plasmodium falciparum. Int J Antimicrob Agents 2017;50:673-677.

$\$ 110$ Totino PR, Lopes SC: Insights into the Cytoadherence Phenomenon of Plasmodium vivax: The Putative Role of Phosphatidylserine. Front Immunol 2017;8:1148.

111 Liu DH, Yao YT, Li LH, Huang CM: Effects of Ulinastatin on In Vitro Storage Lesions of Human Red Blood Cells. Clin Lab 2017;63:833-838.

112 Rodolfo B, Serafina P, Giuseppe B: Mechanisms Involved in the Increased Hemolysis in the Fetus and Newborn. Curr Pediatr Rev 2017;13:188-192.

113 Jemaa M, Fezai M, Bissinger R, Lang F: Methods Employed in Cytofluorometric Assessment of Eryptosis, the Suicidal Erythrocyte Death. Cell Physiol Biochem 2017;43:431-444.

114 Rodak R, Kubota H, Ishihara H, Eugster HP, Konu D, Mohler H, Yonekawa Y, Frei K: Induction of reactive oxygen intermediates-dependent programmed cell death in human malignant ex vivo glioma cells and inhibition of the vascular endothelial growth factor production by taurolidine. J Neurosurg 2005;102:10551068.

115 Stendel R, Stoltenburg-Didinger G, Al Keikh CL, Wattrodt M, Brock M: The effect of taurolidine on brain tumor cells. Anticancer Res 2002;22:809-814.

116 McCourt M, Wang JH, Sookhai S, Redmond HP: Taurolidine inhibits tumor cell growth in vitro and in vivo. Ann Surg Oncol 2000;7:685-691.

117 Wordemann M, Fandrey J, Jelkmann W: Tumor necrosis factor-alpha production by human hepatoma cell lines is resistant to drugs that are inhibitory to macrophages. J Interferon Cytokine Res 1998;18:10691075.

-118 Stendel R, Scheurer L, Schlatterer K, Stalder U, Pfirrmann RW, Fiss I, Mohler H, Bigler L: Pharmacokinetics of taurolidine following repeated intravenous infusions measured by HPLC-ESI-MS/MS of the derivatives taurultame and taurinamide in glioblastoma patients. Clin Pharmacokinet 2007;46:513-524.

119 Harrison HE, Bunting H, Ordway NK, Albrink WS: The Pathogenesis of the Renal Injury Produced in the Dog by Hemoglobin or Methemoglobin. J Exp Med 1947;86:339-356.

120 Vulpis V: Endothelin, microcirculation and hemorheology. Clin Hemorheol Microcirc 1999;21:273-276.

121 Borst O, Abed M, Alesutan I, Towhid ST, Qadri SM, Foller M, Gawaz M, Lang F: Dynamic adhesion of eryptotic erythrocytes to endothelial cells via CXCL16/SR-PSOX. Am J Physiol Cell Physiol 2012;302:C644-C651.

122 Andrews DA, Low PS: Role of red blood cells in thrombosis. Curr Opin Hematol 1999;6:76-82.

123 Chung SM, Bae ON, Lim KM, Noh JY, Lee MY, Jung YS, Chung JH: Lysophosphatidic acid induces thrombogenic activity through phosphatidylserine exposure and procoagulant microvesicle generation in human erythrocytes. Arterioscler Thromb Vasc Biol 2007;27:414-421.

124 Zwaal RF, Comfurius P, Bevers EM: Surface exposure of phosphatidylserine in pathological cells. Cell Mol Life Sci 2005;62:971-988.

125 Abed M, Towhid ST, Mia S, Pakladok T, Alesutan I, Borst O, Gawaz M, Gulbins E, Lang F: Sphingomyelinaseinduced adhesion of eryptotic erythrocytes to endothelial cells. Am J Physiol Cell Physiol 2012;303:C991999.

126 Closse C, Dachary-Prigent J, Boisseau MR: Phosphatidylserine-related adhesion of human erythrocytes to vascular endothelium. Br J Haematol 1999;107:300-302.

127 Gallagher PG, Chang SH, Rettig MP, Neely JE, Hillery CA, Smith BD, Low PS: Altered erythrocyte endothelial adherence and membrane phospholipid asymmetry in hereditary hydrocytosis. Blood 2003;101:46254627.

128 Pandolfi A, Di Pietro N, Sirolli V, Giardinelli A, Di Silvestre S, Amoroso L, Di Tomo P, Capani F, Consoli A, Bonomini M: Mechanisms of uremic erythrocyte-induced adhesion of human monocytes to cultured endothelial cells. J Cell Physiol 2007;213:699-709.

129 Wood BL, Gibson DF, Tait JF: Increased erythrocyte phosphatidylserine exposure in sickle cell disease: flowcytometric measurement and clinical associations. Blood 1996;88:1873-1880. 